Piotr Krzeszowiak

Uniwersytet Wrocławski

Włodzimierz Gromski

Opiekun Naukowy - Scientific Tutor

DOI: $10.19195 / 1733-5779.20 .3$

\title{
Precedensowy charakter uchwał Naczelnego Sądu Administracyjnego
}

JEL classification: K34, K40, K00

Słowa kluczowe: prawo precedensowe, działanie precedensów, źródła prawa, precedensy, orzecznictwo sądowe, zamknięty katalog źródeł prawa, wykładnia prawa, współczesne przemiany w stosowaniu prawa, prawotwórcza rola sądów administracyjnych, prawo sędziowskie, uchwały Naczelnego Sądu Administracyjnego

Keywords: precedent law, action precedents, source of law, precedents, jurisprudence, closed catalog of law sources, interpretation of the law, modern transformations in the use of law, law making role of administrative courts, court law, judge law, resolutions of the Supreme Administrative Court

Abstrakt: W pracy przedstawiono zagadnienie precedensowego charakteru niektórych uchwał Naczelnego Sądu Administracyjnego. Jednocześnie dokonano rozważań na temat prawotwórczej i precedensowej roli sądów administracyjnych. Poruszono zagadnienia współczesnych przemian w stosowaniu prawa, w tym zjawisko przejścia od modelu sylogistycznego do modelu argumentacyjnego stosowania prawa. Ponadto opisano kompetencje Naczelnego Sądu Administracyjnego do podejmowania uchwał mających na celu wyjaśnienie przepisów prawnych, których stosowanie spowodowało rozbieżności w orzecznictwie sądów administracyjnych. W zakończeniu wskazano uchwały Naczelnego Sądu Administracyjnego mające w ocenie autora charakter precedensowy.

\section{Precedential character of resolutions of the Supreme Administrative Court}

Abstract: The article presents the issue of the precedent character of some resolutions of the Supreme Administrative Court. At the same time he deals with the law-making and the precedent role of administrative courts. It deals with the issues of contemporary law change, including the transition from the syllogistic to the paradigmatic application of law. In addition, it describes Competence of the Supreme Administrative Court to adopt resolutions aimed at clarifying legal provisions, the application of which has caused divergences in the case law of administrative 
courts. At the end of the article is presented a review of the resolutions of the Supreme Administrative Court in the author's assessment of the precedent character.

\section{Czy w Polsce możemy mówić o prawie precedensowym?}

Współczesne procesy dyferencjacji społecznej, rozwój nowych technologii, występowanie nowych zjawisk społecznych, rosnący poziom złożoności systemów społeczno-gospodarczych i związany z tym fakt, iż współcześnie prawo staje się instrumentem sterowania coraz bardziej złożonymi procesami społeczno-gospodarczymi, to główne siły sprawcze mechanizmów ewolucji współczesnych systemów prawnych. Pod naporem napięć wynikających z przyczyny intensyfikacji wymienionych zjawisk prawo staje się bardziej otwarte i elastyczne. Skutkuje to tym, że stosowanie prawa coraz mniej przypomina mechaniczne dedukowanie następstw prawnych z reguł prawnych, a coraz częściej staje się mniej lub bardziej skomplikowanym procesem ważenia argumentów. Zauważalny jest proces narastania elementów argumentacyjnych we współczesnych procedurach stosowania prawa. W wyniku owych procesów widoczny jest też wzrost aktywności sądów, co w konsekwencji może powodować wydawanie przez sądy coraz większej liczby orzeczeń precedensowych. Sądy nie mogą ignorować permanentnego nienadążania parlamentów za intensyfikacją przemian społecznych. Skutkuje to jawnym lub ukrytym partycypowaniem w tworzeniu prawa i poprawianiem legislatorów tam, gdzie ich rozwiązania zawodzą. W związku z tym na naszych oczach dochodzi do zmiany dominujących dotąd modeli stosowania prawa1.

Warto zastanowić się, jak ustawodawca radzi sobie z tymi procesami. W mojej ocenie ustawodawca nie nadąża za zmianami, które nieustannie się pojawiają, w wyniku czego tym problemem zostaje obarczony wymiar sprawiedliwości. To wymiar sprawiedliwości, bardzo często bez wsparcia ustawodawcy, musi rozwiązywać realne problemy, których ustawodawca nie jest w stanie przewidzieć. Zastanawiające jest, czy w Polsce możemy mówić o prawie precedensowym. Ewa Łętowska twierdzi, że gdyby myśleć o odpowiedzi na to pytanie w kategoriach tego, czy precedens, jakkolwiek rozumiany, wchodzi do systemu prawa pozytywnego, to oczywiście odpowiedź jest negatywna. Jednakże według niej pytanie dotyczące tej problematyki powinno być inaczej sformułowane. Czy precedens jest elementem procesu decyzyjnego czy to sądu, czy to osoby, która stosuje prawo poza sądem? Jednocześnie, w jaki sposób element tego systemu decyzyjnego jest elementem systemu prawa? ${ }^{2}$ Łętowska stoi na stanowisku, iż obecna organizacja systemu prawa prowadzi prostą drogą ku precedensowi ${ }^{3}$.

${ }^{1}$ L. Morawski, Główne problemy współczesnej filozofii prawa. Prawo w toku przemian, Warszawa 2003, s. 195-196.

2 E. Łętowska, Czy w Polsce możemy mówić o prawie precedensowym, [w:] Precedens w polskim systemie prawa, red. A. Śledzińska-Simone, M. Wyrzykowski, Warszawa 2010, s. 9.

${ }^{3}$ Ibidem, s. 10-14. 
W związku ze stanowiskiem E. Łętowskiej i własnym stanowiskiem niniejszą pracą postaram się wykazać precedensowy charakter niektórych uchwał Naczelnego Sądu Administracyjnego w zaproponowanym przez Łętowską sensie.

\section{Prawotwórczy a precedensowy charakter niektórych decyzji sądów administracyjnych}

Andrzej Stelmachowski definiuje prawotwórczą rolę sądów administracyjnych jako „tworzenie takich norm ogólnych, które nie wypływając z przepisu ustawy, funkcjonują, tak jak gdyby miały za sobą autorytet ustawy"4. Zdaniem Doroty Dąbek charakter prawotwórczy mają: „Orzeczenia sądowe, które wprawdzie zapadają $\mathrm{w}$ sprawach indywidualnych i są formalnie wiążące tylko w tych sprawach, ale ich treść nie została jednoznacznie wyznaczona przez normę prawną, Sąd zmuszony więc był normę prawną doprecyzować lub stworzyć" ". Jak dalej twierdzi autorka: „dotyczy to tych wszystkich przypadków, gdy w ogóle brak było normy prawnej będącej podstawą rozstrzygnięcia Sądu (luka prawna) lub gdy norma prawna będąca podstawą wydawania orzeczenia pozostawiła pewien stopień luzu"6. Jednocześnie należy zauważyć, iż sąd owo rozwiązanie podejmuje, wyłącznie gdy nie ma możliwości zastosowania innego rozwiązania, ponieważ niemożliwe jest ustalenie pełnej treści normy prawnej.

Prawotwórstwo sądów administracyjnych może występować pod różnymi postaciami. Może występować w postaci tworzenia norm o charakterze ogólnymi i abstrakcyjnym, w odróżnieniu od kształtowania norm indywidualnych i konkretnych, rozstrzygających o konkretnym stosunku administracyjnoprawnym ${ }^{7}$. Przykładem prawotwórczej działalności sądów, analizowanej w dalszej części artykułu, są uchwały Naczelnego Sądu Administracyjnego wydawane na podstawie art. $15 \S 1$ pkt 2 p.p.s.a. ${ }^{8}$, wyjaśniające przepisy prawne, których stosowanie wywołuje rozbieżności w orzecznictwie.

Należy wskazać, iż uchwały Naczelnego Sądu Administracyjnego charakteryzowane są jako precedensowe, a nie prawotwórcze, co ma swoje głębsze przyczyny, na co w szczególności zwraca uwagę doktryna ${ }^{9}$. Uważa się, iż precedensem nie jest całe orzeczenie, ale zawarta w sentencji lub uzasadnieniu reguła ogólna,

4 A. Stelmachowski, Prawotwórcza rola sądów administracyjnych (w świetle orzecznictwa cywilnego), „Państwo i Prawo” 1967, z. 4-5, s. 612.

5 D. Dąbek, Prawo sędziowskie w polskim prawie administracyjnym, Warszawa 2010, s. 52.

${ }^{6}$ Ibidem.

7 Ibidem, s. 51.

${ }^{8}$ Ustawa z dnia 30 sierpnia 2002 r. Prawo o postępowaniu przed sądami administracyjnymi (tekst jedn. Dz.U.2016.718 ze zm.), dalej: p.p.s.a.

9 J. Małecki, Kilka uwag o prawotwórczej roli Naczelnego Sąu Administracyjnego w sprawach podatkowych, [w:] Podatki w orzecznictwie sadowym. Zjazd Katedry Prawa Finansowego, Wigry '95, red. E. Ruśkowski, W. Konieczny, Warszawa 1996, s. 18. 
która staje się podstawą przy rozstrzyganiu spraw w przyszłości, za którą podążają następnie sądy administracyjne i organy administracyjne. Teza jest tą częścią orzeczenia, która zostanie uznana za regułę, a wynika to ze sposobu publikacji orzeczenia, ponieważ właśnie teza zostaje wyodrębniona przed treścią orzeczenia. Co do zasady, w uchwałach tezą orzeczenia będzie najczęściej treść odpowiedzi na pytanie prawne, na które dana uchwała udziela odpowiedzi ${ }^{10}$.

Pojęcie precedensu w polskiej doktrynie prawa stanowionego najczęściej definiowana jest jako norma ogólna znajdująca się w orzeczeniu sądowym, która w przyszłości może wpływać na inne decyzje sądowe. Precedens w takiej postaci nie może stanowić $\mathrm{z}$ założenia funkcji prawotwórczej $\mathrm{w}$ rozumieniu tworzenia norm generalnych o powszechnie obowiązującym charakterze. Jednakże należy zwrócić uwagę, iż inną sprawą jest wynik procesu wykładni oraz problem związania sądów administracyjnych wynikiem uchwały abstrakcyjnej Naczelnego Sądu Administracyjnego.

Należy więc zauważyć, że chociaż tworzenie prawa nie jest zadaniem sądów administracyjnych, to doktryna dostrzega $w$ ich działalności takie akty i ich skutki, którym można by przypisać cechy prawotwórcze. Wyjaśnienia tego zjawiska szuka się we wzmożonej aktywności sądów, które coraz częściej podejmują się kreowania ogólnych zasad i reguł ${ }^{11}$.

Wypracowane wzorce zawarte w uchwałach określa się mianem precedensów faktycznych, niewiążących i nieprawotwórczych. Mimo przyjętych fundamentalnych zasad kultury prawa stanowionego, dostrzec można w uchwałach Naczelnego Sądu Administracyjnego funkcje pozaorzecznicze, zbliżające się do prawotwórstwa. Obecnie mówi się o prawotwórstwie faktycznym, czyli o spełnianiu przez niektóre decyzje sądów, funkcji prawodawczych, niesamodzielnych w stosunku do ustaw ${ }^{12}$.

W doktrynie zdania dotyczące prawotwórczego charakteru uchwał Naczelnego Sądu Administracyjnego są rozbieżne. Koncepcje negujące ich prawotwórczy charakter wskazują, że prawotwórstwo nie leży w kompetencji Naczelnego Sądu Administracyjnego, i podważają rozstrzygnięcia w sprawie w tych uchwałach, zarzucając im niedopuszczalność, brak podstawy prawnej i rażące naruszenie prawa. W doktrynie istnieje też postawa umiarkowana, której zwolennicy zakładają, iż akt wykładni prawa nie jest samodzielnym bytem, zatem nie ma żadnych podstaw, aby być aktem prawotwórczym. Twierdzi się, iż nie można obrać bezspornych kryteriów decydujących, co jest tworzeniem prawa, a co jego stosowa-

10 A. Skoczylas, Działalność uchwałodawcza Naczelnego Sądu Administracyjnego, Warszawa 2004, s. 260.

11 L. Morawski, Główne problemy wspótczesnej filozofii prawa. Prawo w toku przemian, Warszawa 2005, s. 240.

12 L. Leszczyński, Zagadnienia teorii stosowania prawa: doktryna i tezy orzecznictwa, Kraków 2004, s. 303. 
niem. Z kolei zwolennicy prawotwórczego charakteru uchwał Naczelnego Sądu Administracyjnego zakładają, że generalny zakaz tworzenia prawa przez sądy jest nieadekwatny do rzeczywistości, a sądy mogą wyręczać ustawodawcę lub stwierdzają, że prawotwórstwo sądów przejawia się najczęściej w nadaniu mocy wiążącej rezultatom wykładni ${ }^{13}$.

\section{Kompetencja Naczelnego Sądu Administracyjnego do podejmowania uchwał mających na celu wyjaśnienie przepisów prawnych, których stosowanie spowodowało rozbieżności w orzecznictwie sądów administracyjnych}

Przedstawiony zostanie tu proces podejmowania przez Naczelny Sąd Administracyjny uchwał mających na celu wyjaśnienie przepisów prawnych, których stosowanie spowodowało rozbieżności w orzecznictwie sądów administracyjnych — art. $15 \S 1$ pkt 2 p.p.s.a. Owa instytucja stanowi kompetencję charakterystyczną sądu sprawującego nadzór judykacyjny ${ }^{14}$.

Nadzór judykacyjny może występować w dwóch formach. W pierwszej formie stanowi on element nadzoru instancyjnego jako właściwości danego sądu w strukturze instancyjnej do rozstrzygania w przedmiocie zasadności zaskarżenia od orzeczeń, w tym wypadku wojewódzkich sądów administracyjnych art. $3 \S 2$ p.u.s.a. ${ }^{15}$ oraz art. $15 \S 1$ pkt 3 p.p.s.a. W drugiej formie przybiera on postać pozainstancyjną, która wynika z art. $3 \S 2$ p.u.s.a. w zw. z art. $15 \S 1$ pkt 2 p.p.s.a. A zatem należy zauważyć, iż możliwość korzystania z prawnoprocesowej instytucji podejmowania uchwał abstrakcyjnych w celu usuwania rozbieżności orzeczniczej może wywoływać żywy spór w doktrynie o pozycję sądu w strukturze podziału władzy państwowej ${ }^{16}$.

Podstawy prawne takiego działania mają swój początek z regulacji ustrojowokompetencyjnej zawartej w art. 184 Konstytucji Rzeczypospolitej Polskiej - Naczelny Sąd Administracyjny oraz inne sądy administracyjne sprawują, w zakresie określonym w ustawie, kontrolę działalności administracji publicznej. Kontrola ta obejmuje też orzekanie o zgodności z ustawami uchwał organów samorządu terytorialnego i aktów normatywnych terenowych organów administracji rządowej ${ }^{17}$. Jednocześnie podstaw prawnych tego działania upatrujemy w art. $3 \S 2$ p.u.s.a. — Naczelny Sąd Administracyjny sprawuje nadzór nad dzia-

13 A. Skoczylas, op. cit., s. 261-267.

14 J.P. Tarano, Prawo o postępowaniu przed sądami administracyjnymi. Komentarz, Warszawa 2004, s. 45.

15 Ustawa z dnia 25 lipca 2002 r. Prawo o ustroju sądów administracyjnych (tekst jedn. Dz.U.2016.1066 ze zm.), dalej: p.u.s.a.

16 Uchwała NSA z dnia 15 czerwca 2011 r., I OPS 1/11, http://orzeczenia.nsa.gov.pl.

17 Konstytucja Rzeczypospolitej Polskiej z dnia 2 kwietnia 1997 r. (Dz.U. 1997 Nr 78, poz. 483). 
łalnością wojewódzkich sądów administracyjnych, w szczególności podejmuje uchwały wyjaśniające zagadnienia prawne oraz rozpoznaje inne sprawy należące do właściwości Naczelnego Sądu Administracyjnego na mocy innych ustaw ${ }^{18}$.

Działalność Naczelnego Sądu Administracyjnego w sytuacji wydawania uchwał abstrakcyjnych wiążących sądy wojewódzkie nie powinna budzić wątpliwości. Niejasność powstaje w momencie rozważenia problemu w kontekście dopuszczalnej ujednolicającej wykładni przepisów prawa do uznania jej za formę sprawowania wymiaru sprawiedliwości. Na podstawie w art. $1 \S 1$ i $§ 2$ p.u.s.a. spotykamy się z pojęciami „wymiar sprawiedliwości” i „kontrola pod względem zgodności z prawem" ${ }^{\prime 19}$. W tym zakresie należy wskazać, iż podejmowane przez Naczelny Sąd Administracyjny uchwały abstrakcyjne są formą realizacji zadań z zakresu ochrony prawnej. W głównej mierze chodzi tu o wykraczające poza sprawowanie wymiaru sprawiedliwości zadanie sądów, jakimi jest zakresowa kontrola legalności prawa. Ważne, iż proces wyjaśniania przepisów prawa w ramach procedury podejmowania uchwał abstrakcyjnych jest związany z wykładnią prawa. Niewątpliwie owe pojęcia można uznać za tożsame, choć w przypadku tej procedury inny jest cel. Tak samo pojmuje ten problem Trybunał Konstytucyjny, który wskazuje, iż „najogólniej ujmując [...] istotą wykładni [...] jest zawsze ustalenie (wyjaśnienie) znaczenia określonego przepisu prawnego, nasuwającego $\mathrm{z}$ różnych względów wątpliwości w sferze stosowania prawa" 20 .

Należy ze szczególną uwagą pochylić się nad art. 269 § 1 p.p.s.a., który stanowi:

Jeżeli jakikolwiek skład Sądu Administracyjnego rozpoznający sprawę nie podziela stanowiska zajętego w uchwale składu siedmiu sędziów, całej Izby albo w uchwale pełnego składu Naczelnego Sądu Administracyjnego, przedstawia powstałe zagadnienie prawne do rozstrzygnięcia odpowiedniemu składowi. Przepis art. 187 § 1 i 2 p.p.s.a. stosuje się odpowiednio.

Jednocześnie należy zauważyć, iż ze względu na przedmiot niniejszej pracy art. $187 \S 1$ p.p.s.a. nie mają istotnego znaczenia, w związku z tym zapis o odpowiednim stosowaniu owego przepisu pozwolę sobie pominąć. Należy jednak zaznaczyć, iż art. 187 § 2 p.p.s.a. stanowi, że „Uchwała składu siedmiu sędziów Naczelnego Sądu Administracyjnego jest w danej sprawie wiążąca".

Fundamentalnym w tej części artykułu jest rozważenie problemu efektywności sprawowania nadzoru pozainstancyjnego rozumianego jako wpływanie na przyszłą praktykę orzeczniczą sądów administracyjnych, która w mojej ocenie ma wiele cech systemu precedensowego.

W następnym punkcie dokonany zostanie przegląd uchwał Naczelnego Sądu Administracyjnego, które w mojej ocenie mają charakter precedensowy.

18 Ustawa z dnia 25 lipca 2002 r. Prawo o ustroju sądów administracyjnych.

19 J.P. Tarano, op. cit., s. 268.

20 Postanowienie TK W12/95 z dnia 26 marca 1996 (Dz.U. 2002 Nr 37, poz. 353). 


\section{Wybrane uchwały Naczelnego Sądu Administracyjnego z zakresu prawa podatkowego}

Pierwszą i jedną z ciekawszych uchwał będzie uchwała w zakresie regulacji źródeł przychodu w ustawie o podatku od osób fizycznych.

Przed Naczelnym Sądem Administracyjnym zostało postawione do rozpoznania zagadnienie prawne budzące istotne wątpliwości: „Czy przychody z uprawiania sportu, o których mowa w art. 13 pkt 2 u.p.d.o.f. ${ }^{21}$, mogą być zaliczone do źródła przychodów z pozarolniczej działalności gospodarczej wymienionego $\mathrm{w}$ art. 10 ust. 1 pkt 3 u.p.d.o.f., jeżeli spełniają kryteria określone w art. 5a pkt 6 u.p.d.o.f.?”22. Uchwałą Naczelny Sąd Administracyjny stwierdził, iż: „Przychody sportowców mogą być zaliczone do źródła przychodów z pozarolniczej działalności gospodarczej (art. 10 ust. 1 pkt 3 u.p.d.o.f.), jeżeli działalność sportowca spełnia kryteria określone $\mathrm{w}$ art. 5a pkt 6 u.p.d.o.f. i nie spełnia kryteriów z art. 5b ust. 1 u.p.d.o.f." 23 .

Należy zauważyć, iż Naczelny Sąd Administracyjny stworzył regułę określającą sposób zaliczenia przychodu do danego źródła przychodu. Jednocześnie tą uchwałą NSA dokonał ciekawego zabiegu, polegającego na uznaniu przychodu z działalności wykonywanej osobiście na rzecz działalności wykonywanej w ramach pozarolniczej działalności gospodarczej. Aby nieco rozjaśnić ten zabieg, należy przytoczyć art. 13 pkt 2 u.p.d.o.f., który stanowi, że za przychody z działalności wykonywanej osobiście, o której mowa w art. 10 ust. 1 pkt 2 u.p.d.o.f., uważa się przychody z osobiście wykonywanej działalności artystycznej, literackiej, naukowej, trenerskiej, oświatowej i publicystycznej, w tym z tytułu udziału w konkursach z dziedziny nauki, kultury i sztuki oraz dziennikarstwa, jak również przychody z uprawiania sportu, stypendia sportowe przyznawane na podstawie odrębnych przepisów oraz przychody sędziów z tytułu prowadzenia zawodów sportowych. Przytoczony przepis nie budzi żadnych wątpliwości. Działalność mieszczącą się w zakresie tej regulacji należy uznawać za wykonywaną osobiście i przypisać ją do takiego źródła przychodu. Jednak sytuacja nieco się komplikuje, gdy działalność z zakresu art. 13 pkt 2 u.p.d.o.f. nosi również znamiona pozarolniczej działalności gospodarczej określonej w art. 5a pkt 6 u.p.d.o.f. i jednocześnie nie nosi znamion działalności nieuznawanej za pozarolniczą działalność gospodarczą określoną w art. 5b ust. 1 u.p.d.o.f. Naczelny Sąd Administracyjny, rozpatrując przedmiotowy problem, ustanowił, że jeżeli działalność z zakresu art. 13 pkt 2 u.p.d.o.f. spełnia przesłanki określone w art. 5a pkt 6 u.p.d.o.f. i nie jest czynnością określoną $\mathrm{w}$ art. $5 \mathrm{~b}$ pkt 1 u.p.d.o.f., wtedy, mimo precyzyjnie określonego art. 13 pkt 2 u.p.d.o.f., przychód z uprawiania

21 Ustawa z dnia 26 lipca 1991 r. o podatku dochodowym od osób fizycznych (tekst jedn. Dz.U.2016.2032 ze zm.), dalej: u.p.d.o.f.

22 Uchwała NSA z dnia 22 czerwca 2015 r., II FPS 1/15, http://orzeczenia.nsa.gov.pl.

23 Ibidem. 
sportu należy zaliczyć do przychodów z pozarolniczej działalności gospodarczej. Takie rozwiązanie tworzy wyjątek od ogólnej zasady z art. 13 pkt 2 u.p.d.p.f., określającej przychód z działalności wykonywanej osobiście na rzecz przychodu z pozarolniczej działalności gospodarczej. Tytułem przykładu można zaznaczyć, że w przedmiotowej uchwale Naczelny Sąd Administracyjny odstąpił od literalnego brzmienia art. 13 pkt 2 u.p.d.o.f., z którego wprost wynika, iż do przychodów z działalności wykonywanej osobiście należy zaliczyć przychody z uprawiania sportu. Literalnie interpretując art. 13 pkt 2 u.p.d.o.f., należy stwierdzić, iż determinujący w tym przypadku jest sam fakt uprawiania sportu. A zatem z literalnego brzmienia przepisu wynika, iż każdy przychód osiągany z uprawiania sportu powinien być zaliczony jako przychód z działalności wykonywanej osobiście niezależnie od formy prawnej, w jakiej znajduje się dany sportowiec otrzymujący przychody z uprawiania sportu. W związku z tym uzasadnione jest twierdzenie, że przedmiotowa uchwała ustanawia regułę polegającą na wyłączeniu spod jurysdykcji art. 13 pkt 2 u.p.d.o.f. przychodów osiąganych z uprawiania sportu, jeżeli sportowiec uprawia sport w formie pozarolniczej działalności gospodarczej, co w mojej ocenie nie znajduje żadnej podstawy w przepisach prawa podatkowego i powoduje stworzenie wyłączenia od regulacji określonej w art. 13 pkt 2 u.p.d.o.f., a tym samym stwarza precedens, więc przedstawiona uchwała przejawia charakter precedensowy.

Następnie rozpatrzymy drugą uchwałę, która w mojej ocenie pośrednio w ustawie o podatku dochodowym od osób fizycznych tworzy wyłączenie w definicji przychodu.

Przed NSA powstało zagadnienie prawne budzące poważne wątpliwości:

czy pomimo zapisu wynikającego z art. 10 ust. 1 pkt 8 lit. a) u.p.d.o.f. przewidującego jako źródło przychodów odpłatne zbycie nieruchomości lub ich części oraz udziału w nieruchomości, w świetle art. 19 ust. 1 i 3 u.p.d.o.f. możliwe jest określenie tego przychodu w oparciu o sformułowane w tym ostatnim przepisie kryteria, w przypadku zbycia następującego w drodze umowy o dożywocie $^{24}$.

Artykuł 11 u.p.d.o.f. stanowi, że co do zasady przychodem są otrzymane lub postawione do dyspozycji podatnika w roku kalendarzowym pieniądze i wartości pieniężne oraz wartości otrzymanych świadczeń w naturze i innych nieodpłatnych świadczeń. Jednocześnie nie można zapomnieć o art. 10 ust. 1 pkt 8 lit. a) u.p.d.o.f., który stanowi, iż źródłami przychodów są odpłatne zbycie nieruchomości lub ich części oraz udział w nieruchomości, z zastrzeżeniem art. 10 ust. 2 u.p.d.o.f., który stanowi, iż art. 10 ust. 1 pkt 8 u.p.d.o.f. nie stosuje się (pkt 1) do odpłatnego zbycia na podstawie umowy przewłaszczenia w celu zabezpieczenia wierzytelności, (pkt 2) w formie wniesienia wkładu niepieniężnego do spółki lub spółdzielni środków obrotowych oraz (pkt 3) w przypadku wniesienia pod

${ }^{24}$ Uchwała NSA z dnia 17 listopada 2014 r., II FPS 4/14, http://orzeczenia.nsa.gov.pl. 
pewnymi warunkami składników majątku, o których mowa w art. 14 ust. 2 pkt 1 u.p.d.o.f.

Należy zauważyć, iż w art. 10 ust. 2 u.p.d.o.f. ustawodawca jasno i precyzyjnie określił wyłączenia, do których nie stosuje się regulacji z art. 10 ust. 1 pkt 8 lit. a) u.p.d.o.f. Warte uwagi jest, iż w wyłączeniach określonych w art. 10 ust. 2 u.p.d.o.f. nie znajduje się rozpatrywane przez NSA zbycie nieruchomości na podstawie umowy dożywocia. To spowodowało powstanie problemu budzącego poważne wątpliwości, który uchwałą Naczelny Sąd Administracyjny starał się rozwiązać: „W przypadku zbycia nieruchomości na podstawie umowy o dożywocie nie jest możliwe określenie przychodu ze źródła, o którym mowa w art. 10 ust. 1 pkt 8 lit. a u.p.d.o.f., na zasadach wynikających z art. 19 ust. 1 i 3 u.p.d.o.f."25. W konsekwencji NSA pośrednio w drodze precedensu dodał do katalogu wyłączeń $\mathrm{z}$ art. 10 ust. 2 u.p.d.o.f. kolejną formę zbycia nieruchomości, która z powodu niemożności określenia przychodu, zgodnie z art. 19 ust. 1 i 3 u.p.d.o.f., nie podlega reżimowi art. 10 ust. 1 pkt 8 lit. a u.p.d.o.f. W mojej ocenie takie rozwiązanie stanowi kategorię wyłączenia, którego podstawy nie znajdziemy w przepisach prawa podatkowego. Toteż stwierdzenie przez Naczelny Sąd Administracyjny, iż przychód z odpłatnego zbycia nieruchomości w drodze darowizny nie jest możliwy. W konsekwencji powoduje to wyłączenie takiego zbycia nieruchomości spod jurysdykcji art. 10 ust. 1 pkt 8 lit. a u.p.d.o.f. Takie rozwiązanie skutkuje realnym rozszerzeniem katalogu wyłączeń określonym w art. 10 ust. 2 u.p.d.o.f. Moim zdaniem to stwierdzenie potwierdza, iż przedmiotowa uchwała nosi znamiona aktu precedensowego.

W kolejnej uchwale Naczelny Sąd Administracyjny dokonał wyłączenia z kategorii przychodu odpłatnego zbycia nieruchomości wykorzystywanej na potrzeby związane z działalnością gospodarczą, lecz nieujętą w ewidencji środków trwałych owej działalności. W przytaczanym przypadku Rzecznik Praw Obywatelskich wniósł do Naczelnego Sądu Administracyjnego o podjęcie uchwały mającej na celu wyjaśnienie zagadnienia prawnego. W przedmiotowym wniosku zadano pytanie:

Czy przychód z działalności gospodarczej w rozumieniu art. 14 ust. 2 pkt 1 lit. a u.p.d.o.f. stanowi przychód $\mathrm{z}$ odpłatnego zbycia nieruchomości lub ich części lub udziału w nieruchomości, wykorzystywanych na potrzeby związane z działalnością gospodarczą, które nie były ujęte w ewidencji środków trwałych oraz wartości niematerialnych i prawnych oraz które nie stanowią składników majątku wskazanych w art. 14 ust. 2c u.p.d.o.f.? ${ }^{26}$

Można tu przytoczyć art. 14 ust. 2 pkt 1 lit. a) u.p.d.o.f., który stanowi, iż przychodem z działalności gospodarczej są również przychody z odpłatnego zbycia składników majątku będących środkami trwałymi albo wartościami niematerialnymi i prawnymi, podlegającymi ujęciu w ewidencji środków trwałych oraz war-

25 Ibidem.

${ }^{26}$ Uchwała NSA z dnia 17 lutego 2014 r., II FPS 8/13, http://orzeczenia.nsa.gov.pl. 
tości niematerialnych i prawnych. Jednocześnie należy zauważyć, iż regulacja $\mathrm{z}$ art. 14 ust. 2c u.p.d.o.f. stanowi, iż do przychodów, o których mowa w ust. 2 pkt 1 , nie zalicza się przychodów z odpłatnego zbycia wykorzystanych na potrzeby związane $\mathrm{z}$ działalnością gospodarczą oraz przy prowadzeniu działów specjalnych produkcji rolnej: budynku mieszkalnego, jego części lub udziału w takim budynku, lokalu mieszkalnego stanowiącego odrębną nieruchomość lub udział w takim lokalu, gruntu lub udziału w gruncie albo prawa użytkowania wieczystego gruntu lub udziału w takim prawie, związanych z tym budynkiem lub lokalem, spółdzielczego własnościowego prawa do lokalu mieszkalnego lub udziału w takim prawie oraz prawa do domu jednorodzinnego w spółdzielni mieszkaniowej lub udział w takim prawie. Jak wynika z przytoczonej regulacji, za przychód z działalności gospodarczej uznawane są przychody z odpłatnego zbycia składników majątkowych znajdujących się w ewidencji środków trwałych. Jednocześnie art. 14 ust. 2c u.p.d.o.f. dokonuje wyłączenia od instytucji przychodu, w którym mieści się odpłatne zbycie wykorzystywanych na potrzeby związane z działalnością gospodarczą: budynki mieszkalne, grunty, spółdzielcze własnościowe prawo do lokalu oraz prawo do domu jednorodzinnego.

Uchwałą z dnia 17 lutego 2014 roku Naczelny Sąd Administracyjny rozszerzył katalog wyłączeń z art. 14 ust. 2c u.p.d.o.f., ustanawiając, iż:

W stanie prawnym obowiązującym od dnia 1 stycznia 2004 r. nie stanowi przychodu z działalności gospodarczej w rozumieniu art. 14 ust. 2 pkt 1 lit. „a” u.p.d.o.f. odpłatne zbycie nieruchomości lub ich części oraz udziału w nieruchomości, wykorzystywanych na potrzeby związane z działalnością gospodarczą, które nie były ujęte w ewidencji środków trwałych oraz wartości niematerialnych i prawnych, a które nie stanowią składników majątku wskazanych w art. 14 ust. 2c u.p.d.o.f. 27

Stwierdzeniem „nie stanowi przychodu z działalności gospodarczej” Naczelny Sąd Administracyjny dokonał kolejnego wyłączenia z kategorii przychodu z działalności gospodarczej odpłatnego zbycia nieruchomości lub ich części, które nie były ujęte $\mathrm{w}$ ewidencji środków trwałych, lecz były wykorzystywane na cele związane z tą działalnością. W mojej ocenie przytoczona uchwała $\mathrm{z}$ uwagi na skutek, jaki powoduje, ma precedensowy charakter.

Ostatnia wybrana uchwała dotyka problematyki wygasania zobowiązań podatkowych. Przed NSA w trybie art. 187 § 1 p.p.s.a. postawiono do rozstrzygnięcia następujące pytanie prawne: ,czy zapłata, o której mowa w art. $59 \S 1$ pkt 1 w zW. z art. $60 \S 1$ pkt 2 o.p. w brzmieniu obowiązującym w 2004 r., dokonana przez inny podmiot $\mathrm{w}$ imieniu podatnika, powoduje wygaśnięcie zobowiązania podatkowego tego podatnika?"28. Naczelny Sąd Administracyjny podjął uchwałę, w której stwierdził, że: „zapłata, o której mowa w art. 59 § 1 pkt 1 o.p. w zw.

\footnotetext{
27 Ibidem.

28 Uchwała NSA z dnia 26 maja 2008 r., I FPS 8/07, http://orzeczenia.nsa.gov.pl.
} 
z art. $60 \S 1$ pkt 2 o.p., w brzmieniu obowiązującym w 2004 r., dokonana przez inny podmiot $\mathrm{w}$ imieniu podatnika nie powoduje wygaśnięcia zobowiązania podatkowego tego podatnika" 29 . Ta uchwała potwierdziła powszechnie obowiązujący pogląd, że żaden inny podmiot nie może skutecznie wygasić zobowiązania podatnika poza nim samym. Tym samym potwierdzony został pogląd, że wyłącznie podatnik może dokonać wygaśnięcia swojego zobowiązania podatkowego w drodze zapłaty.

Najistotniejsza w rozpatrywanej uchwale jest jednak ostatnia część uzasadnienia:

należy wszakże wyraźnie zaakcentować, że powyższe rozważania nie dotyczą sytuacji, w której osoba wpłacająca podatek dokonuje tego ze środków powierzonych mu przez podatnika. Dokonuje wówczas czynności technicznej - wpłaca podatek za podatnika, działa jednak jedynie jako „posłaniec”. Bogumił Brzeziński nazywa taką osobę „wyręczycielem” (B. Brzeziński, M. Kalinowski, M. Masternak, A. Olesińska), B. Dauter „przekazicielem środków podatnika” (S. Babiarz, B. Dauter, B. Gruszczyński, R. Hauser, A. Kabat, M. Niezgódka-Medek). Należy zaznaczyć, że nie są to pojęcia o charakterze normatywnym. Chodzi tu o osobę, która dokonuje faktycznej wpłaty podatku, wpłacając środki otrzymane od podatnika, np. pracownik podatnika w ramach powierzonych obowiązków udaje się do urzędu skarbowego i wpłaca w kasie środki od niego otrzymane, czy też krewny podatnika wyręczając go, dokonuje zapłaty z jego środków. W tych bowiem wypadkach zapłaty w sensie prawnym dokonuje podatnik, nie zmienia tego faktyczne wyręczenie podatnika w przekazaniu jego środków do kasy organu podatkowego ${ }^{30}$.

Cytowane uzasadnienie stało się podstawą do utrwalenia praktyki potwierdzanej również przez sądy i organy skarbowe. Wspomniana praktyka polegała na wpłacaniu zobowiązań podatkowych za podatnika przez inne podmioty. Wynikiem owej uchwały było stworzenia quasi-podmiotu nazywanego „posłańcem” lub „wyręczycielem”, który przy spełnieniu określonych warunków, mimo powszechnego zakazu wygasania zobowiązań przez inne podmioty, jeżeli dokona wpłaty w charakterze „posłańca” lub „wyręczyciela”, spowoduje skuteczne wygaśnięcie zobowiązania.

W mojej ocenie takie stwierdzenie można uznać za regułę ogólną, bez wątpienia będącą podstawą przy rozstrzyganiu spraw w przyszłości. To wprost świadczy o precedensowym charakterze przedmiotowej uchwały. Warto zaznaczyć, iż owa uchwała znalazła powszechną aprobatę wśród sądów administracyjnych i organów skarbowych, co zostało potwierdzone licznymi indywidualnymi interpretacjami podatkowymi, między innymi: interpretacja indywidualna z dnia 14 czerwca 2011 r. wydanej przez Dyrektora Izby Skarbowej w Poznaniu ${ }^{31}$, interpretacja indywidualna z dnia 21 czerwca 2010 r. wydanej przez Dyrektora Izby

29 Ibidem.

30 Ibidem.

31 Interpretacja indywidualna z dnia 14 czerwca 2011 r. wydanej przez Dyrektora Izby Skarbowej w Poznaniu sygn. ILPB1/415-376/11-4/AO, http://sip.mf.gov.pl/. 
Skarbowej w Warszawie ${ }^{32}$, interpretacja indywidualna z dnia 11 czerwca 2013 r. wydanej przez Dyrektora Izby Skarbowej w Łodzi ${ }^{33}$.

\section{Konkluzje odnoszące się do wybranych uchwał Naczelnego Sądu Administracyjnego}

Jak wynika z przedstawionego katalogu uchwał Naczelnego Sądu Administracyjnego, ich moc sprawcza, legitymowana art. 269 § 1 p.p.s.a. w związku z art. 15 $\S 1$ pkt 2 p.p.s.a., może prowadzić do interesujących wniosków. Niewątpliwie na mocy art. $269 \S 1$ p.p.s.a. w związku z art. $15 \S 1$ pkt 2 p.p.s.a. można stwierdzić, iż nieuwzględnienie odrębnego stanowiska sądu rozpatrującego sprawę, przez odpowiedni skład lub pełny skład Naczelnego Sądu Administracyjnego, powoduje związanie sądu rozpatrującego daną sprawę rozwiązaniem, które starano się zakwestionować. W mojej ocenie przytoczona regulacja daje możliwość uchwalania precedensowych orzeczeń, które w konsekwencji mają charakter źródeł prawa. Nawet przy ostrożnym podejściu do tej kwestii należy stwierdzić, iż brakuje jasności i precyzji przy określaniu charakteru oraz pozycji uchwał Naczelnego Sądu Administracyjnego w systemie źródeł prawa.

Odpowiednie będzie tu przytoczenie poglądu Romana Hausera i Marka Wierzbowskiego, iż „wszystkie Sądy Administracyjne są związane stanowiskiem wyrażonym w uchwale do chwili, gdy nastąpi zmiana stanowiska NSA"34. Nadto autorzy zaznaczają, że „Interpretacja przepisów prawa wyrażona w uchwale NSA jest pośrednio wiążąca zarówno dla zwykłych, jak i dla rozszerzonych składów orzekających" 35 .

W związku z tym należy rozważyć pogląd Przemysława Sztejny, iż stanowisko zajęte w uchwale abstrakcyjnej przez właściwy skład Naczelnego Sądu Administracyjnego wiąże wszystkie składy orzekające sądów administracyjnych, dopóki nie nastąpi zmiana tego stanowiska ${ }^{36}$. Można zastanowić się nad stanowiskiem prezentowanym przez tego autora, który uważa, iż

w tym przypadku nie można wskazać na podejmowanie przez Naczelny Sąd Administracyjny tego rodzaju aktów jako formę niedopuszczalnego prawotwórstwa, w szczególności dlatego, że ukształtowanie prawne tej instytucji jest tego rodzaju, iż akt interpretujący nie ma charakteru normatyw-

32 Interpretacja indywidualna z dnia 21 czerwca 2010 r. wydanej przez Dyrektora Izby Skarbowej w Warszawie, sygn. IPPB1/415-394/09/10-5/S/JB; http://sip.mf.gov.pl/.

33 Interpretacja indywidualna z dnia 11 czerwca 2013 r. wydanej przez Dyrektora Izby Skarbowej w Łodzi, sygn. IPTPB3/4230-11/13-2/GG; http://sip.mf.gov.pl/.

34 R. Hauser, M. Wierzbowski, Prawo o postepowaniu przed sadami administracyjnymi. Komentarz, Warszawa 2015, s. 269.

35 Ibidem.

36 P. Sztejna, Jednolitość stosowania prawa przez sądy administracyjne - problematyka prawna podejmowania uchwat abstrakcyjnych przez Naczelny Sad Administracyjny, [w:] Prawotwórstwo sądów administracyjnych, red. J.P. Tarano, T. Bąkowski, Warszawa 2015, s. 275. 
nego przepisu prawa ani powszechnej mocy obowiązujące, ale zmierza (na przyszłość) do ujednolicania praktyki stosowania prawa przez sądy administracyjne, co jest cechą pożądaną, związaną z pewnością prawa ${ }^{37}$.

W związku z tym można dojść do wniosku, iż uchwały NSA graniczą już ze sferą tworzenia prawa. Uchwały abstrakcyjne jako generalne akty wykładni prawa znajdują się między konstytucyjnymi źródłami prawa a orzeczeniami indywidualno-konkretnymi ${ }^{38}$. Takie twory o cechach aktu indywidualnego i konkretnego, które nie zostały wymienione w konstytucyjnym katalogu źródeł prawa, od strony praktycznej funkcjonują poniekąd jako źródła prawa, to znaczy kreują znaczenie i sposób interpretowania normy prawnej w sposób wiążący ${ }^{39}$.

W ramach podsumowania, odnosząc się do pytania E. Łętowskiej zacytowanego na początku niniejszego artykułu „Czy precedens jest elementem procesu decyzyjnego czy to sądu, czy to osoby, która stosuje prawo poza sądem?" ${ }^{40}$, po przeanalizowaniu wybranych uchwał Naczelnego Sądu Administracyjnego, w mojej ocenie nie sposób się nie zgodzić ze stanowiskiem autorki, która twierdzi, iż obecna organizacja systemu prawa prowadzi prostą drogą ku precedenso$\mathrm{wi}^{41}$, co w mojej ocenie zostało potwierdzone wybranymi uchwałami Naczelnego Sądu Administracyjnego.

\section{Bibliografia}

Bojanowski E. Utrwalona linia orzecznicza (kilka uwag na marginesie orzecznictwa sądów administracyjnych), [w:] Między tradycja a przyszłościa w nauce prawa administracyjnego. Księga jubileuszowa dedykowana profesorowi Janowi Bociowi, red. J. Supernat, Wrocław 2009.

Dąbek D., Prawo sędziowskie w polskim prawie administracyjnym, Warszawa 2010.

Fleming-Kulesza T., Czy w Polsce możemy mówić o prawie precedensowym, [w:] Precedens w polskim systemie prawa, red. A. Śledzińska-Simone, M. Wyrzykowski, Warszawa 2010.

Gomułowicz A. [w:] A. Gomułowicz, J. Małecki, Podatki i prawo podatkowe, Warszawa 2013.

Hauser A., Kabat A., Uchwaty Naczelnego Sadu Administracyjnego w nowych regulacjach procesowych, „Państwo i Prawo” 2004, z. 2.

Hauser R., Wierzbowski M., Prawo o postępowaniu przed sądami administracyjnymi. Komentarz, Warszawa 2015.

Leszczyński L., Zagadnienia teorii stosowania prawa: doktryna i tezy orzecznictwa, Kraków 2004. Leszczyński L., Wojciechowski B., Zirk-Sadowski M., Wyktadnia w prawie administracyjnym, [w:] System Prawa Administracyjnego, t. 4. L. Leszczyński, M. Zirk-Sadowski, B. Wojciechowski, Wyktadnia w prawie administracyjnym, Warszawa 2012.

37 Ibidem, s. 277.

38 E. Bojanowski, Utrwalona linia orzecznicza (kilka uwag na marginesie orzecznictwa sqadów administracyjnych), [w:] Między tradycją a przyszłościa w nauce prawa administracyjnego. Księga jubileuszowa dedykowana profesorowi Janowi Bociowi, red. J. Supernat, Wrocław 2009, s. 50.

39 Ibidem, s. 142.

40 E. Łętowska, op. cit., s. 9.

${ }^{41}$ Ibidem, s. 10-14. 
Łętowska E., Czy w Polsce możemy mówić o prawie precedensowym, [w:] Precedens $w$ polskim systemie prawa, red. A. Śledzińska-Simone, M. Wyrzykowski, Warszawa 2010.

Małecki J., Kilka uwag o prawotwórczej roli Naczelnego Sądu Administracyjnego w sprawach podatkowych, [w:] Podatki w orzecznictwie sadowym. Zjazd Katedry Prawa Finansowego, Wigry '95, red. E. Ruśkowski, W. Konieczny, Warszawa 1996.

Morawski L., Główne problemy współczesnej filozofii prawa. Prawo w toku przemian, Warszawa 2003.

Morawski L., Główne problemy współczesnej filozofii prawa. Prawo w toku przemian, Warszawa 2005.

Skoczylas A., Działalność uchwałodawcza Naczelnego Sadu Administracyjnego, Warszawa 2004.

Stelmachowski A., Prawotwórcza rola sądów administracyjnych ( $w$ świetle orzecznictwa cywilnego), „Państwo i Prawo” 1967, z. 4-5.

Sztejna P., Jednolitość stosowania prawa przez sady administracyjne - problematyka prawna podejmowania uchwat abstrakcyjnych przez Naczelny Sąd Administracyjny, [w:] Prawotwórstwo sądów administracyjnych, red. J.P. Tarano, T. Bąkowski, Warszawa 2015.

Tarano J.P., Prawo o postępowaniu przed sadami administracyjnymi. Komentarz, Warszawa 2004.

\section{Wykaz uchwał i postanowień}

Uchwała NSA z dnia 15 czerwca 2011 r., I OPS 1/11, http://orzeczenia.nsa.gov.pl.

Uchwała NSA z dnia 17 listopada 2014 r., II FPS 4/14, http://orzeczenia.nsa.gov.pl.

Uchwała NSA z dnia 17 lutego 2014 r., II FPS 8/13, http://orzeczenia.nsa.gov.pl.

Uchwała NSA z dnia 22 czerwca 2015 r., II FPS 1/15, http://orzeczenia.nsa.gov.pl.

Uchwała NSA z dnia 26 maja 2008 r., I FPS 8/07, http://orzeczenia.nsa.gov.pl.

Postanowienie TK W12/95 z dnia 26 marca 1996 (Dz.U. 2002 Nr 37 poz. 353).

\section{Wykaz indywidualnych interpretacji podatkowych}

Interpretacja indywidualna z dnia 14 czerwca 2011 r. wydanej przez Dyrektora Izby Skarbowej w Poznaniu sygn. ILPB1/415-376/11-4/AO; http://sip.mf.gov.p1/.

Interpretacja indywidualna $\mathrm{z}$ dnia 21 czerwca $2010 \mathrm{r}$. wydanej przez Dyrektora Izby Skarbowej w Warszawie, sygn. IPPB1/415-394/09/10-5/S/JB; http://sip.mf.gov.pl/.

Interpretacja indywidualna $\mathrm{z}$ dnia 11 czerwca $2013 \mathrm{r}$. wydanej przez Dyrektora Izby Skarbowej w Łodzi, sygn. IPTPB3/4230-11/13-2/GG; http://sip.mf.gov.p1/.

\section{Wykaz aktów prawnych}

Konstytucja Rzeczypospolitej Polskiej z dnia 2 kwietnia 1997 r. (Dz.U. 1997 Nr 78, poz. 483).

Ustawa z dnia 30 sierpnia 2002 r. Prawo o postępowaniu przed sądami administracyjnymi (tekst jedn. Dz.U.2016.718 ze zm.) [p.p.s.a.].

Ustawa z dnia 25 lipca 2002 r. Prawo o ustroju sądów administracyjnych (tekst jedn. Dz.U.2016.1066 ze zm.) [p.u.s.a.].

Ustawa z dnia 26 lipca 1991 r. o podatku dochodowym od osób fizycznych (tekst jedn. Dz.U.2016.2032 ze zm.) [u.p.d.o.f.].

Ordynacja podatkowa (tekst jedn. Dz.U.2015.613 ze zm.) [o.p.].

Studenckie Prace Prawnicze, Administratywistyczne i Ekonomiczne 20, 2016

(C) for this edition by CNS 


\section{Precedential character of resolutions of the Supreme Administrative Court}

\section{Summary}

As is clear from the presented catalog of resolutions of the Supreme Administrative Court, their power of action, based on art. $269 \S 1$ Polish act of the administrative court proceedings (p.p.s.a.) in connection with art. $15 \S 1$ pkt. 2 Polish act of the administrative court proceedings (p.p.s.a.), can lead to interesting conclusions. Undoubtedly, power of art. $269 \S 1$ Polish act of the administrative court proceedings in connection with art. $15 \S 1$ pkt. 2 Polish act of the administrative court proceedings, leads to a statement that the resolution of the composition of the seven judges or of the entire composition is binding for the future for all other administrative courts. In my opinion, the above-mentioned regulation gives the possibility of passing precedent judgments, which consequently have the character of sources of law. Even with a cautious approach to this issue, it should be stated that there is no clarity and precision in defining the nature and position of resolutions of the Supreme Administrative Court in the system of sources of law.

It will be relevant here to quote the views of $\mathrm{R}$. Hauser and M. Wierzbowski, who argue that "all Administrative Courts are bound by the position expressed in the resolution until a change in the position of the Supreme Administrative Court occurs. In addition, the authors also point out that "Interpretation of legal provisions expressed in the Supreme Administrative Court resolution is indirectly binding both for ordinary and extended adjudicating courts. Consequently, consideration should be given to the view taken by P. Sztejn, who points out that the position adopted by the Supreme Administrative Court in the abstract resolution binding all the compositions of the administrative courts until such a change is made.

Therefore, it can be concluded that resolutions of the Supreme Administrative Court are already binding on the sphere of lawmaking. Abstract resolutions as general acts of interpretation of law are between the constitutional sources of law and individual-concrete judgments. Such creations with the characteristics of individual and concrete acts, which are not mentioned in the constitutional catalog of sources of law, practically function as sources of law, they create the meaning and interpretation of the legal norm in a binding way.

As a summary, referring to E. Łętowska question, quoted at the beginning of this article, "Is a precedent part of the decision-making process or is it a court or a person who applies law outside of court?" After analyzing selected resolutions of the Supreme Administrative Court, in my opinion, it is impossible to disagree with the position of E. Lętowska, who claims that the current organization of the legal system leads a straight path to the precedent, which in my opinion was confirmed by selected resolutions of the Supreme Administrative Court. 